\title{
THEATRICALITY OF FILM LANGUAGE IN BAZ LUHRMANN'S FILMS
}

\author{
MICHAELA MALÍČKOVÁ and JURAJ MALÍČEK \\ Institute of Literary and Artistic Communication at the Faculty of Arts, \\ Constantine the Philosopher University in Nitra, Slovakia
}

\begin{abstract}
The aim of the study is to identify such strategies that reveal the theatrical quality of film language in the movies of Australian director, screen writer, and producer Baz Luhrmann, and to examine how they reflect the development of his poetics as an auteur. Theatricality defines his first three film projects Strictly Ballroom (1992), Romeo + Juliet (1996) and Moulin Rouge! (2001), therefore they are together referred to as the so called Red Curtain Trilogy. The explication of ties to theatre that characterizes Luhrmann's oeuvre reveals the connection between various types of stage, and staging, as well as the specific qualities and development of Luhrmann's directorial style, and his understanding of film, and its language. Luhrmann's film image is complex in the semiotic reading, each detail has an aesthetic, and semantic value often due to the disposition of film language. Luhrmann's artworks remain in a number of cases saturated by his performative vision of the world. The degree and specific quality of film language such as ostension (manifested as illusionism, meticulously arranged mise-en-scène, and aestheticized sets, and costumes or pompous carnivalesque musical and dancing show), camp, and citations are closely examined in feature films such as Australia (2008) and The Great Gatsby (2013), in the series of short staged interviews between two icons of fashion world Schiaparelli and Prada: Impossible Conversations (2012) and in the TV series The Get Down (2016 - 2017). These cultural products also confirm their connection to theatre and their author's interest in various stage forms reflecting on culture based on a play principle.
\end{abstract}

Keywords: theatricality of film language, aesthetic ostension, camp, citation, popular culture

The existence of film as presented in the films by Australian director, script writer, and producer Baz Luhrmann can be interpreted as a self-contained manifestation of artistic and craft skills of a contemporary auteur; an author who is an artist, sole creator, and orchestrator of his works. In the contemporary mainstream Hollywood production he represents a type of a director who is both a successful film auteur and the director who knows the rules of film market, and who does not think of film as strictly taken artwork, however, who approaches film as a marketable commodity. Such an approach in an immediate production practice means that the auteur is in the final product, in the artwork present not only as its immediate creator, but the one who acts also as its executive producer - participating in the artistic as well as financial responsibility for a possible success/ failure of the artwork. ${ }^{1}$ The complexity of Luhrmann as a film auteur is predefined by his experience in theatre. He understands film as an artistic form that is on one hand autonomous - understood from

\footnotetext{
${ }^{1}$ For more of the concept of auteur in the history of cinema see e.g. THOMPSON, K. - BORDWELL, D. Dějiny filmu. Přehled světové kinematografie [History of Film: An Introduction]. Praha : Akademie múzických umění a Nakladatelství Lidové noviny, 2011, p. 427.
} 
the perspective of its sign system, however, on the aesthetic level it represents only another form of dramatic art. In his understanding film is a specific version, a direct continuation of theatre poetics, and its development.

When Baz Luhrmann shot his first film Strictly Ballroom in 1992 he had been a renowned theatre director, and playwright who turns his own theatre production of a dramatic text he had co-authored into a film. He wrote the theatre play Strictly Ballroom $^{2}$ as a student of The National Institute of Dramatic Arts in Sydney with his script writing collaborator Craig Peace and playwright Andrew Bovell. The play is the pars pro toto example supporting Luhrmann's primary identity as a drama person: a playwright, actor, theatre director.

\section{Film Begins, Theatre Continues}

The film Strictly Ballroom ${ }^{3}$, retroactively identified as the first part of the so called Red Curtain Trilogy, can be interpreted in this context as a self-referential manifesto of an author looking for his own expressive language. All three films of the trilogy - Strictly Ballroom (1992), Romeo + Juliet (1996) a Moulin Rouge! (2001) ${ }^{5}$ - are autonomous regarding their stories, connected by the idea of a red curtain, a theatrical production principle.

The organisation of space, the arrangement of a set, and props, and staging of events in the mise-en-scène is the passion that Luhrmann ostentatiously demonstrates in his films. The red curtain in all three cases stands for the stage. While in each of the projects it has a slightly different form, together the three of them meet the idea of triadic choreia ${ }^{6}$. The first part of the trilogy pays homage to dance as an art. The stage is a dance floor and all other places where it is possible to dance on. The second part, Shakespearean, honours the language of poetry that can sound as splendid on the Elizabethan stage as on a beach, in a swimming pool as well as on a desert. The third part, is a musical, and shows respect to music, the music capable of narrating the story as persuasively as a cabaret or Bollywood spectacle. The used explication strategy foregrounding the links between theatre and film in Luhrmann's trilogy discloses not only relationships between various types of stage and staging strategies but also the development of Luhrmann's directorial style and his vision of film and its language.

\footnotetext{
${ }^{2}$ In 1986 Baz Luhrmann, as a fresh graduate of the National Institute of Dramatic Arts in Sydney participated in the Istropolitana Projekt festival, then called The International Festival of Drama Academies, in Bratislava, socialist Czechoslovakia, first time organised in 1977. Together with Craig Pearce they presented an extended version of originally a students' performance of Strictly Ballroom, that was successfully staged in The Wharf Theatre in Sydney.

${ }_{3}^{3}$ Strictly Ballroom, directed by B. Luhrmann. Australia, 1992. $94 \mathrm{~min}$.

${ }^{4}$ Romeo + Juliet, directed by B. Luhrmann. USA, 1996. $120 \mathrm{~min}$.

${ }^{5}$ Moulin Rouge!, directed by B. Luhrmann. Australia/USA, 2001. $123 \mathrm{~min}$.

${ }^{6}$ The concept of choreia including music, poetry and dance in close coexistence, is used in W. Tatarkiewicz's History of Aesthetics I in connection with expressive arts (in contrast to constructive arts - architecture, sculpture and painting), while the concept of choreia itself is primarily used in dance. See TATARKIEWICZ, W. Dejiny estetiky I. Staroveká estetika [History of Aesthetics. I: Ancient Aesthetics]. Bratislava : Tatran, 1985, p. 13. At the same time the triad refers to dithyramb as a complex hymnic form sang at the beginning by the Ancient Greek choir that gradually gave rise to theatre genres and forms as some of its parts became autonomous. See SOURIAU, É. Encyklopedie estetiky [Vocabulaire d'esthétique]. Praha : Victoria Publishing, 1994, p. 190 and p. 342.
} 


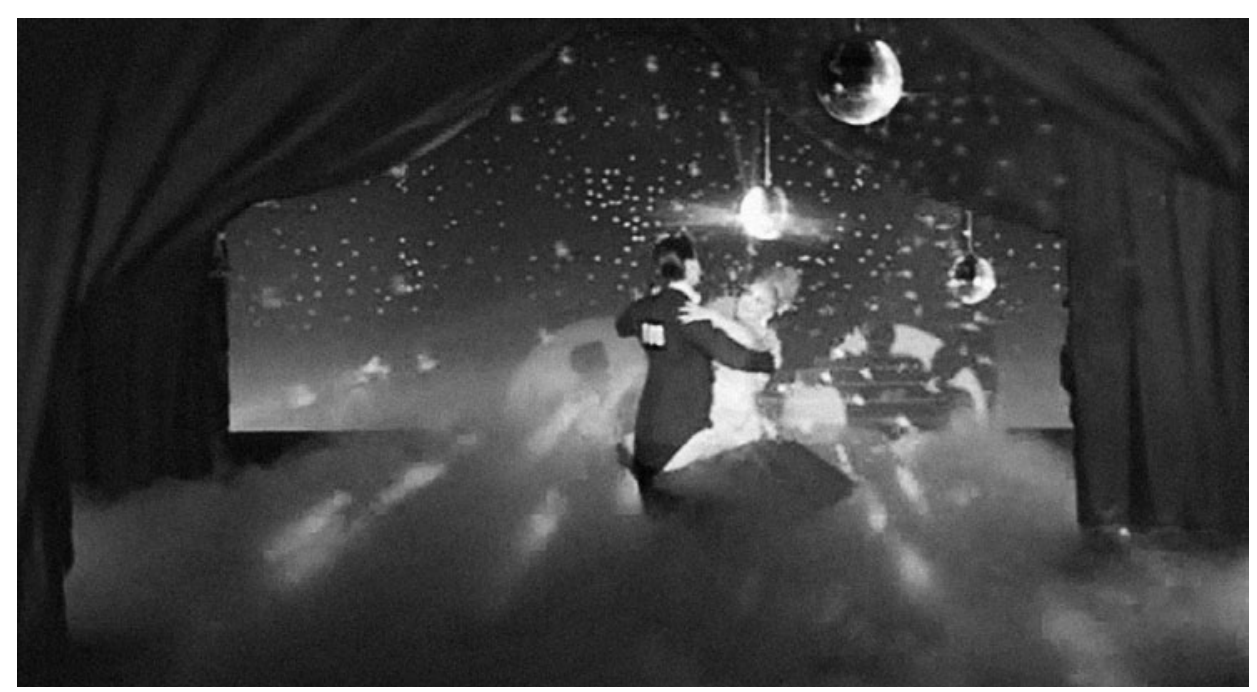

Strictly Ballroom. The red curtain also serves as a frame for memories - as it turns out in the story, the memories are staged, and thus modified, and stylised in the same way as their narrator.

The storyline of the film Strictly Ballroom links together three model narratives, invariants, varying the story of Prometheus in the David and Goliath, Cinderella, and Ugly Duckling narratives. The topoi of the story introduces the audience into the milieu of professional ballroom dancers tied by strict formal conventions that prevent dancers be creative. The status quo is disturbed by a dancer (David) who rebels against the conventions and together with his new partner (Cinderella, Ugly Duckling) wins over the system represented by a stiff representative of dance establishment (Goliath). The film unmistakably contains the romantic motive of impossible, but because of that even more devout love, as well as the motive of injustice and the secret from the past that needs to be fixed, and the motive of awakening at the end of the story when the community supports the outcasts, and they become heroes eventually. The story, build up on the above mentioned cliches and platitudes, ends in a majestic happy ending, however, the motives that could surprise the audience in terms of the unexpected fulfilment do not emerge. The film Strictly Ballroom ends in a cliche the same way as it begins with a cliche. What makes it unique and unforgettable is its form, it attempts to find alternatives to staging theatre techniques in expressive means of film.

Already in the first sequence of the film Luhrmann undermines the stereotypical way of representation in lighting. The image is unusually lighter in the introductory scene presenting the milieu and main characters. The camera vantage point includes also a hidden source of light, and as a result the image on the screen is blurred. The shot is overexposed, not only literally but also metaphorically. By presenting the close-ups of jurors' faces it is more a caricature than a representation. The jurors' exaggerated facial expressions, visible in close-ups incorporate the means of expression typical mostly for a theatrical way of character representation. The film thus becomes artificially literal, the quality that Luhrmann accentuates through the use of dialogues 


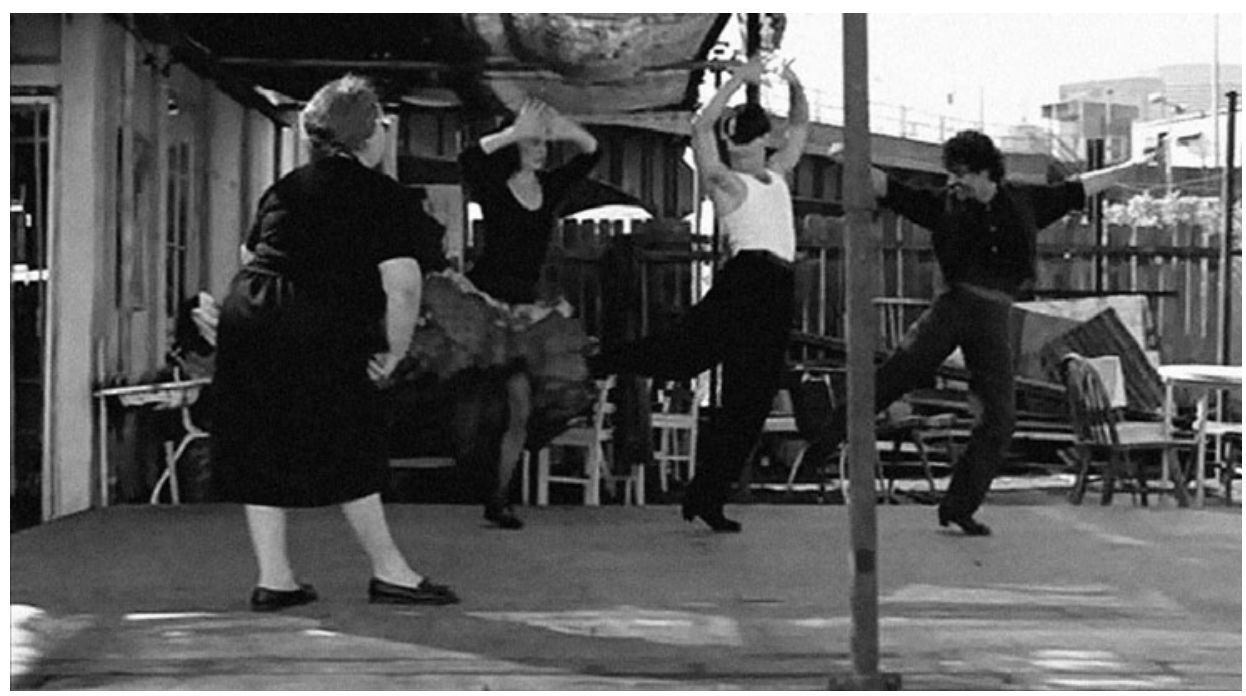

Strictly Ballroom. Dance floor is everywhere - on the stage, on the roof, and on the terrace.

where without any hint of irony the plot is directly anticipated - the characters in dialogues recite what exactly happens the next moment. Therefore the shot bears the idealised form of a narration barren of any ambiguity. The audience watches the story of rebellion, dreams coming true, and romantic love in its most natural environment where the metaphysics of love finds its physical pendant in partner dances. The ballroom dancing itself is a theatrical production. Not only by its stage-like quality (i.e. it takes place on a stage) but also by the fact that it is a ritualised stage production of the erotic that needs the fourth wall to preserve the aesthetic distance.

Another layer of the film in discussion reveals Luhrmann's natural theatricality ${ }^{7}$ in specific directorial strategies. Individual dialogic and dancing sequences are staged as autonomous dramatic entries with their own dramaturgy; they create a narrative whole thanks to juxtaposition, however, they can be divided into smaller, independent fragments. Last but not least, Luhrmann can be identified as a theatrical film director because he uses the stage design, scenery, set, and costumes functionally, moreover, he pays attention to the expressive function of the mise-en-scène, and the employment of sound, and music. The result is a meticulously aestheticized form that is in every moment orchestrated for the spectator. The awareness of permanent presence of the spectator strengthens the ostension of expression in all film elements starting with the actor's performance and ending with the set.

${ }^{7}$ Theatricality as a formal specification of experienceness of expression is in the reception aesthetics of the Nitra School defined as the "ability to communicate in a complex way through signs. The meaning in the process of communication is created through visual, and acoustic signs, characters, and story while these are tied to histrionism, and are used in contrast to literariness, and naturality. See PLESNÍK, L'. et al. Tezaurus estetických výrazových kvalit [Thesaurus of Aesthetic and Expressive Qualities]. Nitra : Univerzita Konštantína Filozofa, 2008, pp. $411-418$. 


\section{Ostension, Camp, Citation}

Already in Luhrmann's first film the specific quality of the aesthetic ostension is constituted. It is a unique auteur signature identifiable in all his other projects. It makes the audience to re-evaluate their reception approach, and undermines their conventions of taste. Luhrmann's aesthetic ostension can be identified by both semantic poles discussed by theatre theoretist Ivo Osolsobě: ostension as a communication by the means of non-signs in the line of Augustinian tradition, i.e. as showing, the direct mimetic representation recognisable by the eyes, without mediation of signs, and also ostension in terms of Eco's communication model: ostension signs that are homomaterial with their referent. ${ }^{8}$

Luhrmann in a creative collaboration with his wife costume designer Catherine Martin ${ }^{9}$ managed to create authentic and exceptional style that puts together passion for theatrically stylised stage and visual qualities of film image. In Luhrmann's films simple and straightforward stories meet gaudy orchestrated aesthetics, and are saturated with meanings that erase the boundaries between the so called high and low. At the same time the authentication theatre principle of "here and now" that is principally impossible in cinema Luhrmann successfully compensates and constitutes a new principle of "then and there".

Therefore the common expressive feature of Luhrmann's films is such a model of film reality whose referential reality is not our world (i.e. the external ontological reality) but a stylised, and in that sense idealised, fictional world stretched to maximum limits. In spite of its hyperbolic representation it is devoid of irony, sarcasm, and everything that forces the recipient to perceive with suspicion the honesty of expression and the purity of ideas. A cynical person could identify a kitsch. An ironic person, aesthetician, Eco's learned spectator identifies camp, in other words "the art that presents itself seriously, however, it cannot be taken that much seriously because there is an 'excess' of it."10

The aesthetics of Romeo + Juliet, Moulin Rouge!, or The Great Gatsby is an open polemics with the traditional understanding of beauty. It needs to be extreme, contrasting, striking, and emotional. It flirts with kitsch that is manifested loudly as an elementary expressive stylistic principle of narration. It is a kitsch conceptually situated, bound to the poetics of film narration, the kitsch that is internalised, transformed into camp. Camp is only its surface, appearance, it is a lifestyle, carnivalesque event, decadent experience, it is experienced therefore truthful. As a result it is liminal, ambivalent, relative, and relativizing, constantly changing its dynamics. Grotesque, therefore tragic, and at the same time elevated by the elements of comedy, frivolous entertainment, and visual provocation. Camp in Luhrmann's film is a quality that can be safely identified as a result of author's strategy ignoring the limits of what can

${ }^{8}$ OSOLSOBĚ, I. Principia parodica totiž Posbírané papíry převážně o divadle [Principia parodica, i.e. Collected Papers on Theatre]. Praha : Akademie múzických umění, 2007, pp. 84 - 92.

${ }_{9}^{9}$ Their common projects were mostly awarded by nominations specifically for costumes and production design (among them BAFTA Awards for Best Production Design in 1993 for Strictly Ballroom, in 1998 for Romeo + Juliet, Academy Awards for Best Costume Design and Best Production Design in 2002 for Moulin Rouge! and for The Great Gatsby in 2014 can be mentioned).

${ }^{10}$ SONTAG, S. Poznámky o fenoménu camp [Notes on "Camp"]. In Labyrint Revue, 2000, Vol. 8, Issue $7-8$, p. 83 . 
be staged. It creates the autonomous fictional world, with a clearly specified objectivisation framework of reality, although, without being defamiliarised by fantasy. Such framework of reality pulls down the fourth wall through a symbolic "then and there" similarly to "here and now" in traditional theatre context. Camp here is the enthusiastic kitsch as a result of intentional and pre-programmed excessiveness freeing the recipient from obscure reading where what the recipient can see may symbolise something else from what is seen. The eclecticism and stylistic hybridisation contribute to the accomplished form of Luhrmann's film language, the fact that corresponds on one hand with the logic of camp, as well as with the principle of creating intertextual links, another of unmistakably identifiable director's narrative strategies. He accumulates the semantic layers into the references, paraphrases, allusions, citations, and opens the space for the audience to engage in investigation. It could seem that the intertextual relationships and strategies are typical mostly for younger media working with an enormous repertoire of tools. However, as Ivo Osolsobě points out, the citation is "non-linguistic, theatrical, histrionic way of shaping, and each citation, quasi-citation and particularly pseudo-citation, is in fact theatre. How close the citation is to theatre can be illustrated also by everyday utterances - the moment we cite the utterance of someone else, we usually start not only citing the other person, we exactly imitate, impersonate the person." ${ }^{11}$ The citation is "something essentially close to theatre."12 Therefore the citation throws us back to the core of theatre-mimesis. And the most cited dramatic texts in the cultural tradition are the texts of William Shakespeare.

\section{Romeo + Juliet}

In Luhrmann's rendition the Shakespeare's classics is a film that not only respects the theatrical quality of the pretext it honours the Shakespeare's text, and overtly, and intentionally reconstructs it in a new medium. When examining the character of Shakespeare's dramatic text ${ }^{13}$ it comes out that it is a posttext ${ }^{14}$, simi-

${ }^{11}$ OSOLSOBĚ, I. Principia parodica totiž Posbírané papíry převážně o divadle [Principia parodica, i.e. Collected Papers on Theatre]. Praha : Akademie múzických umění, 2007, p. 221.

12 Ibid.

${ }^{13}$ Originally, the tragic story of Romeo and Juliet is based on a medieval Italian story and its literary version can be traced back to the 15th century, although Verona's Romeo and Juliet can be found already in 1530. There are a few Italian versions known from the 16th century, and also the translations to French, and English. It seems Shakespeare was inspired by several materials, mostly by the poetic translation by Arthur Brook. For more see e.g. Notes by Zdeňek Stř́brný in SHAKESPEARE, W. Tragedie I. [Tragedies I]. Praha : Státní nakladatelství krásné literatury, hudby a umění, 1958, p. 117.

${ }^{14}$ The terminology of intertextuality by T. Žilka is used in the text. The key relationship takes place between a pretext, the original text, and a posttext, the secondary text that can respond to the pretext in various ways. Žilka follows the theory of intertextual links by A. Popovič that came to origin as a result of his interest in the theory of translation and also the theory of West European intertextuality. It rather follows the adaptation theories than topical concepts of intermediality, and in Popovič's understanding text is a category that is higher than the concept of medium. The authors of this article follow a broader tradition of West European intertextuality, it comes back to Bakhtin's understanding of language as a dialogue, where the "other" is always present (as an utterance saturated in a different framework of values, language as carrier of the world perspective), his understanding of genre (in a broader linguistic not only artistic terms) as a new understanding of reality, to a discursive reading by Julia Kristeva, to Eco's open text and towards Fiske's intertextual identity of popular culture. 


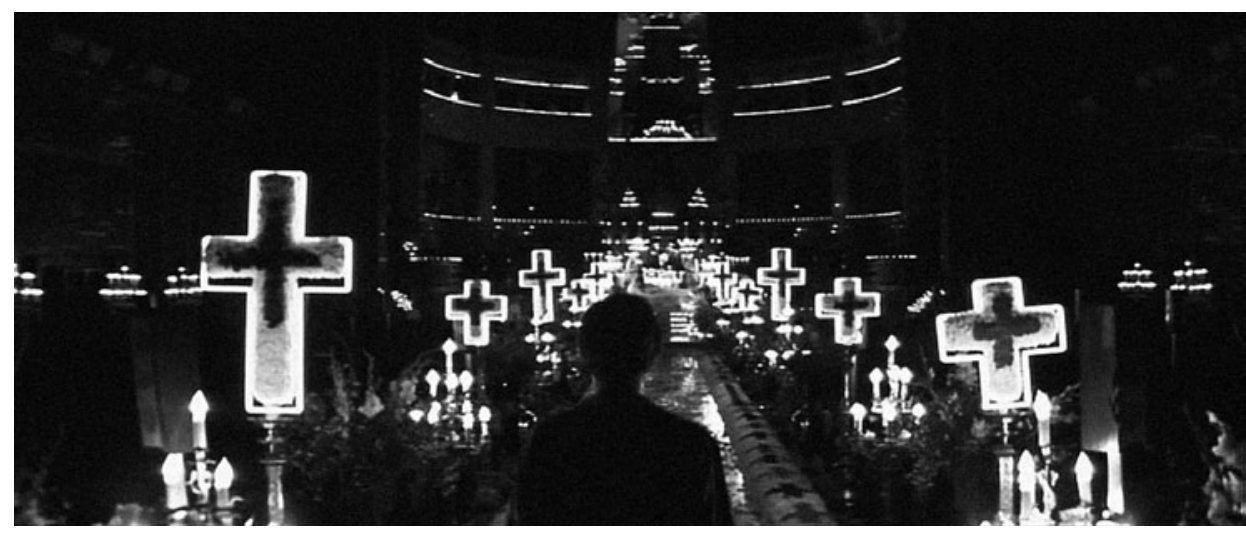

Romeo + Juliet. The death of the lovers in a tomb is also staged as a grandiose visual scene accentuating the omnipresent spectator.

larly the film adaptation is also essentially intertextual, more precisely, an intermedia project.

The English playwright preserves the tragic character of the text, however, it creates the space for the clash of the contrasts. The genre ambiguity is achieved by the elements of humour, farce, grotesque, therefore the depiction of the world that emerges is vibrant, persuasive, and its story is realistic. By mixing the emotions the author creates the intertextual relationships on the genre level, while he constructs them also on the formal and linguistic levels. As translator Zdeněk Stříbrný points out in the footnotes accompanying the Czech translation of Shakespeare's Tragedies: "The whole tragedy is saturated both with high poetic language and raw, earthy colloquial language. In addition to manly jokes, and cunning word-puns a number of artful and artistic forms of Medieval and Renaissance lyrical poetry come into play." 15 No wonder Luhrmann chose exactly Romeo and Juliet to pay homage to the language of poetry since Shakespeare's linguistic creativity fascinated the world already at the time of its origin. The linguistic play on words is not purposeless since there are many word puns in modern English that Shakespeare created. As the authors of Essential Shakespeare Handbook affirm "many Shakespeare's new words reflect the active contact between English and other live languages"16, in his "English a whole range of marked linguistic features is reflected, the language that was flexible to the changing world of users, and therefore itself was subject to substantial changes."17

Luhrmann uses original Shakespeare's language and even though balancing between the genres - so typical for his oeuvre, he deepens the dispositions of the pretext. He respects the dominant tragic dimension of the text that is always counterbalanced (also thanks to the spectacular visual aesthetics) through playfully romantic

${ }^{15}$ STříBRNÝ, Z. Poznámky (Notes). In SHAKESPEARE, W. Tragedie I. [Tragedies I]. Praha : Státní nakladatelství krásné literatury, hudby a umění, 1958. p. 13.

${ }^{16}$ DUNTON-DOWNER, L. - RIDING, A. Shakespeare. Základná príručka [The Essential Shakespeare. Handbook]. Bratislava : Ikar, 2006, p. 42.

${ }^{17}$ Ibid. 


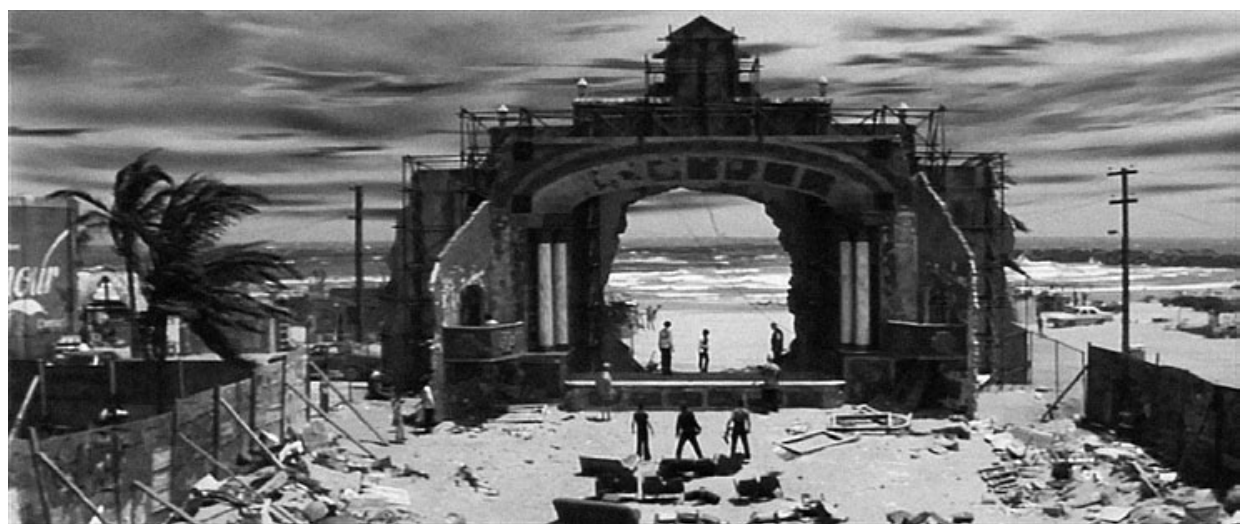

Romeo + Juliet. Mercutio dying in the ruins of the Elizabethan theatre.

or lightened farcical scenes to stay outside the pathos. Even though he updated the Shakespeare's pretext in the extraordinary chronotope, he respects, and understands the original text. Regarding the plot the film is true to the pretext, with only partial eliminations. The most significant change of the plot is the elimination of the character of Paris from the scene in the tomb, where Romeo comes to say good-bye to Juliet. Luhrmann does not kill Paris, neither Romeo's mother - in the pretext she dies of grief because of Romeo's banishment. Therefore the audience is more attentive to a young couple's story, and their death is not only one of many. In director's version he allows them to say good-bye to each other, in a precious moment, when Juliet wakes up from the effects of potion and Romeo really dies. It is a moment of risky balance on the borderline among sentiment, pathos, and kitsch that renders the intensive feeling of helplessness - it is the scene the audience could not watch in a real theatre, however, it is possible to be watched in film as a cathartic moment. The natural aesthetic distance of film medium protects the audience against the feeling of inappropriate voyeurism, while at the same time the spectacularly arranged place of the lovers' suicide and the way of presentation of such an intimate moment prove that the audience is welcome.

To mediate the specific atmosphere of the Renaissance time when the belief in God clashes with the growing belief in oneself, and at the same time to mediate the modern story required the intertextual logic also when creating the film chronotope. The setting is the combination of cultural environments (Elizabethan world and dominant culture of the contemporary Western world) creating a compact, authentic unity. It is an entirely universal city, as the director points out, similarly to Shakespeare's Verona that was a mythical place, it is a hot weathered version of period London. ${ }^{18}$ A film portrait of Verona Beach is linked to multicultural codes of American culture with the focus on Latino aesthetics, with the expressions conveying religiosity and a high degree of stylisation. Religious relics, symbols of faith are a part of commonness. The Christian iconography decorates weapons, houses, billboards. It can be

${ }^{18}$ LUHRMANN, B. - MALONE, P. Baz Luhrmann. Interview, 19 December 1996. [online]. [cit. 10 May 2020]. Available at: http://petermalone.misacor.org.au/tiki-index.php?page=Baz+Luhrmann\&bl. 
found on clothing, and dominates the gaudy tattoos that can be found even on Father Lawrence's back. Although the moving eye of the camera mediates the iconography to the audience, the representation is a part of the logic used in theatre for costumes and building up characters identity.

The key topos acquiring the theatrical function with the dimensions of a stage is the so called Sycamore Grove - a part of the beach Romeo and his friends find the place of refuge. It has a narrative significance, it is a meeting point of socially and culturally different worlds, blending the world of reality and fiction. Next to poor slums there are the ruins of Elizabethan theatre that always functions as a provisional stage. Here the audience meets Romeo, the Montagues start the carnival at the Capulets, here the nurse and Romeo negotiate the marriage with Juliet, and it is exactly this place where Mercutio curses both families when he dies at Tybalt's hands. The two scenes stand in juxtaposition - the scene of Mercutio dying in the ruins of the Elizabethan theatre at the presence of onlookers watching it as a performance that is exclusively theatrical, and the following scene of Mercutio's murderer Tybalt followed and slain by Romeo - built upon numerous detailed shots, dynamic camera, and fast editing, and thus being exclusively filmic.

Erecting the ruins of the Elizabethan theatre over the vast surface of the ocean, on the territory of no-one, and everyone, is the homage not only to the theatre of Shakespearean times, but theatre as a world perspective. The director pays attention and carefully stages the filial relationship between film and theatre, and composes the whole story as a stage event. Eventually, in Juliet's tomb Romeo also enters the stage - literally - to perform his last act. At the same time, however, Luhrmann employs the film language specifically with the focus on the narration qualities of image. It is exactly the image that fundamentally transforms the theatre story into a film story. The Elizabethan theatre was more a sound than visual experience. Because of the power of the image Luhrmann can cross out one third of the original text and does not diminish the story in details nor the atmosphere. Using the image Luhrmann substitutes textual eliminations, he adds up another meaning layer, he whispers to the audience.

\section{Staging, Choir, and a New Type of Character}

The director of Romeo + Juliet organises each scene, each image with the conscious focus on the spectator. The artificiality of the image with a high degree of stylisation combined with the solely poetic Shakespearean language ceases to create unwanted reception distance in the moment when the spectator realises that the whole party is here only and only for him or her. The spectator is important, the spectator is omnipresent. There are witnesses to each event - passers-by, randomly present, Peeping Toms, but also the participants, who sometimes only helplessly watch. Moreover, the whole story is conceived as an event for the television viewer. A TV screen - modern stage, on one hand defamiliarises the story of forbidden love, on the other hand it presents the story as a real event that can be conveyed only because the media was there. Luhrmann makes no space for confusion we are the viewers of the TV news. The very introductory image presents the TV screen and the presenter on it by the words of Shakespeare's choir announcing the dramatic events of the last days: riots caused by the feud of two powerful families ended by the death of young lovers, 
descendants of the enemy families. The media is always present, to cover, to bring the evidence, to show, to comment. In the past the analogical function in the theatre was attributed to the choir, and the choir similarly to the TV medium was a narrator with some influence.

Although the choir in the Shakespeare's text appears only twice - in the prologue and then before the balcony scene - its function is significant. In the theatre tradition the choir plays a key role. It was the involved narrator or as a case may be the co-narrator of the story, in various degrees and in various ways involved in the plot. It was a collective character, ambivalent in meaning and expression. It was connected with the metaphysical authority, it was a mediator between the godlike and human, analogically, it was a linking element between the stage and auditorium. The choir generalised, evaluated, encouraged, discouraged, undermined, and relativised. Gradually its role changed to a trusted person or a companion, his collective essence was transformed into individual characters. Although the importance of the choir in the west European theatre tradition varied, it did not disappear completely. It was originally an active, later only commenting, or as a case may be didactic collective character personalised in the characters of jokers, fools, harlequins reminding the audience of the ambivalent value of events presented on the stage and strengthening thus not only didactic, but really cathartic influence of the performance. ${ }^{19}$ Therefore the choir on one hand preserves the aesthetic distance protecting the line between reality and fiction in theatre, on the other hand it secures the individual could acquire more universal validity and thus deepens the effect of what as an orchestrated illusion takes place on the stage. In this ambivalence, i.e. in the ability to create the aesthetic distance and at the same time to reinforce the cathartic effect of the artwork, the true reception effect of the choir rests.

The Shakespeare's dramatic texts were created in the time when the choir had no longer a strong position in the structure of a play. The playwright, however, did not give up on the function of the choir, although he used it sparsely and its function corresponds with the position of a narrator. It is, however, a kind of omniscient narrator who can comment on the situation with the insight. Although Shakespeare wrote along the tradition, where the choir acts only as an individual at the beginning of the play and at the beginning or at the end of individual acts, he creates some characters in such a way that they refer to the choir's character and function. A part of choir's responsibilities is moved to the character of Father Lawrence, who in Luhrmann's version literally takes over the function of the choir when he repeats the words of the prologue. If his ambition would not be to transform the individual desires to a general welfare he could be called the biggest intrigue maker in the story. He sees the events from a bird's perspective, the same way as the choir, however, he understands them a little bit more than a regular mortal being. He is a priest, and a scholar, and the director accentuates his ability to envision by a psychedelic experience. Father Lawrence makes up complicated plans that go beyond control, because he simply cannot fulfil the function of deus ex machina and direct the events toward happy ending. However, paradoxical it may seem, the Father Lawrence represents the unpredictability of destiny, ambivalence, and impermanence of being. "Just as Dante surpasses

${ }^{19}$ The weakening of the significance of choir characters initiated the discussion, for example in the $18^{\text {th }}$ century known as the so called dispute on Harlequin (e.g. in texts by G. W. Lessing). 
all other writers, before or since, in emphasising an ultimate changelessness in each of us, a fixed position that we must occupy in eternity, so Shakespeare surpasses all others in evidencing a psychology of mutability" ${ }^{20}$ literary critic Harold Bloom asserts in his book The Western Canon: The Books and School of Ages, and adds: "Dante interprets his characters for you; if you cannot accept his judgements, his poem abandons you. Shakespeare so opens his characters to multiple perspectives that they become analytical instruments for judging you." 21

Bloom thinks of Mercutio, Falstaff, Hamlet and other Shakespeare's characters to be a new type of a character, through which Shakespeare "originates the depiction of self-change on the basis of self-hearing". ${ }^{22}$ Mercutio, always ironizing, provoking, and seemingly aloof, is a counterbalance to Romeo's romantic enchantment and saturation with emotions. Mercutio has to comment everything around him from the above; he wants to understand what happens, to make a standpoint. And exactly this is the way he is the character affiliated with the choir, he is the liminal character in "between". He is neither the Capulet nor the Montague, he has the access to both worlds. The moment he chooses where he ultimately stands, he is no longer untouchable like the choir, and he dies. The delicate balance of the story is definitively broken, and Mercutio saying: "A plague o' both your houses!" ${ }^{23}$ becomes a prophet, conjuror. Luhrmann's Mercutio is a bohemian, in his character the Apollonian aloofness and Dionysian voluptuousness meet. He is a clown with a tragic end, an entertainer who, fully conscious of it, alleviates the burden and seriousness of life.

All the above mentioned attributes turn Luhrmann's version of Romeo + Juliet into a modern story, yet, the audience can recognise the past seeping in. This contrast is both audio and visual. The audience can listen to the several centuries old poetic text blended with pop songs, gospels, shooting, and the sound of helicopters, there is modern streetwear and also opulent carnival gowns with the touch of the past, protagonists in villas that could be easily Renaissance palaces, though equipped with swimming pools where the balcony scenes take place with the most romantic declarations of love. There is the carnival where definitely, any distinctions are erased: an astronaut dances with an angel, a transvestite is accompanied by a medieval monk, and a long time enemy can be a guest at the ball for a moment.

The carnivalesque experience of the world is an integral part of the ostentatious aesthetics of Luhrmann's film and another natural link to Shakespeare. Theatre theorist Milan Lukeš in his book Between Carnival and Dream asserts that the "lyricism of Romeo and Juliet that is ostentatiously presented in the form of sonnets (...) is immediately accompanied by equally strong ostentatiousness of carnival experience and a worldview. Its protagonist is the character of Mercutio whose violent death in the middle of the play is not only to remove a secondary character that is suddenly too much - Mercutio's death equals to the assassination of a temporary king of carnival. With Mercutio's death as if the carnival, the time of revel, ended, and the Lent

${ }^{20}$ BLOOM, H. Kánon západní literatury [The Canon of Western Literature: The Books and School of Ages]. Praha : Prostor, 2000, p. 58.

${ }^{21}$ Ibid., p. 74

${ }^{22}$ Ibid., p. 59.

${ }^{23}$ SHAKESPEARE, W. Tragedie I. [Tragedies I]. Praha : Státní nakladatelství krásné literatury, hudby a umění, 1958, p. 63. 
would begin." 24 The interpretation perspective of carnival aesthetics affirms Mercutio's choir identity, and his importance in the story. His death can be interpreted as a narrative and genre rupture.

Similarly to its dramatic pretext the film Romeo + Juliet is ambivalent in expression, is bipolar in terms of the genres and it is mannerist. ${ }^{25}$ It is ultra stylish, visually beautiful - again up the limits of kitsch, it is gaudy, expressive, emotionally tense, it is campy. And it is a crème de la crème film perspective of the period experience in Shakespeare's Romeo and Juliet.

\section{Musical as an Intertext}

When practicing the discursive reading of Luhrmann's oeuvre Moulin Rouge! is an interesting example specifically as a self-referential example to various stage strategies (from cabaret to great Bollywood spectacle), the process of writing, staging, rehearsing and production of theatre performance. It is the final project of the Red Curtain Trilogy and in the most evident reception code it can be read as the postmodern homage to the greatest of all themes - love.

The postmodernist reading of the traditional story, narrated in the form of a classical musical comes as a result of intertextual coding such as (a) the layering of several stories and several meanings in one narrative, (b) the poetics of allusions and citations reinterpreting pretexts from the reservoir of pop cultural memory, (c) the carnival eclecticism of styles and cultural codes, (d) self-reflectivity of narrative forms, staging principles and forms of entertainment. ${ }^{26}$

The leitmotiv of immortal love covers also other stories (on place, on time, on people, truth, beauty, and freedom), it supports the uniting theme of the trilogy, and corresponds with the dynamics of pop culture with the return of grand themes through grandiose narratives. A story of a young inexperienced writer who falls in love with a courtesan dying of tuberculosis and who tries to save his beloved refers on the level of the intertext invariant to two model stories of tragic love: to the mythical story of Orpheus, who follows his Eurydice to the underworld, and to the romantic version of the tragic novel from the $19^{\text {th }}$ century La Dame aux Camélias by Alexandre Dumas, fils, who borrowed the narrative dominants of the story from Manon Lescaut by Abbé Prévost from the $18^{\text {th }}$ century.

In addition to the dominant love story Moulin Rouge! also develops the story of an artist's personal growing and maturation. It is exactly this code where it is possible to understand the film as the self-referential study of narrative forms. The audience follows the story of the artist infatuated with a courtesan, in the process of his writing he creates a story for the theatre that is analogical to his real life. As the story he cre-

${ }^{24}$ LUKEŠ, M. Mezi karnevalem a snem. Shakespearovské souvislosti [Between Carnival and Dream. Shakespeare and the Others]. Praha : Divadelní ústav, 2004, p. 87.

${ }^{25}$ In Milan Lukeš' view Romeo and Juliet is the Shakespeare's tragedy with the highest degree of mannerism. Lukeš asserts this can be one of the possible reasons for the long term tragedy's popularity. See ibid., p. 87.

${ }^{26}$ For more on the intertextual quality of the film Moulin Rouge! see MALÍČKOVÁ, M. Významotvorná povaha medzitextových väzieb v popkultúrnych textoch [Making Meaning through Intertextual Links in Pop Culture Texts]. In Teória umeleckého a prekladového textu: tradicie a inovácie [Theory of Artistic and Translation Text: Traditions and Innovations]. Nitra : UKF, 2015, pp. $167-188$. 


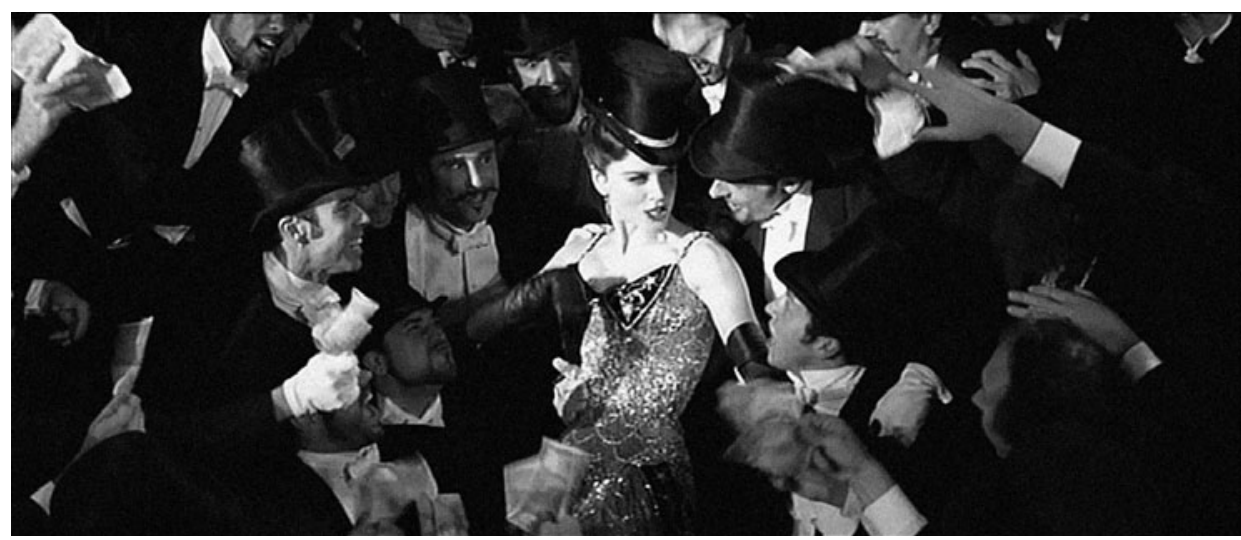

Moulin Rouge! The performance of Satine in Moulin Rouge paraphrasing Marilyn Monroe and her Diamonds are a Girl's Best Friend.

ates comes into existence in the process of writing, it emerges on another ontological level in the rehearsal of a theatre production. The story enters the story, the ontological reality of the film blends with the theatrical fiction that is the part of the plot; both stories influence one another, their plots alternate, and thus also possible endings. The Duke, an investor financing the theatre production, is rejected, and cheated on by Satine, the courtesan, he demands the ending be changed. He threatens he kills Christian and forces Satine to dump him. The betrayed lover analogically to the myth of Orpheus returns to the underworld, in the case of the story to the performance in Moulin Rouge - a contemporary underworld, and at the end he changes both stories in favour of true love. Although the love of two specific people is defeated by death (both in the reality of film and the fictional text) the semantic invariant does not change. Therefore the idea of pure unconquerable love remains untouched and the postmodern relativisation is replaced by the pop culture ideality.

The stage is the space where the story of tragic love, passion, and jealousy is played out repeatedly, in many variations, for example during the song El Tango de Roxanne, where the dramatic plot culminates shortly before the story takes another direction and starts to be dominantly tragic. All these stories, tied together by a common intertextual invariant, multiply, and internally affirm one another, or modify, foreshadow alternative endings, blur or blend. They are Christian's novel, the script to the theatre performance, staged theatre event, narration in the backstage, and Christian's personal story. His personal story does not come to the audience directly, however, is narrated by Toulouse, a harlequin who welcomes the audience singing: "There was a boy..." Toulouse, again, is the character deeply rooted in the theatre tradition, it is a choir character. He belongs among jokers, fools, bums, outcasts - characters on the borderline between the worlds, oscillating in expression. Toulouse is a comic tragedian, a limping dwarf, favoured, and also unloved, and therefore desiring love even more knowing its real value. He is the most truthful of characters in Moulin Rouge! It is exactly him who arranges the encounter of future lovers, it is him who protects their love, who at the most decisive moment reminds them of its value, and confirms that the story standing over 


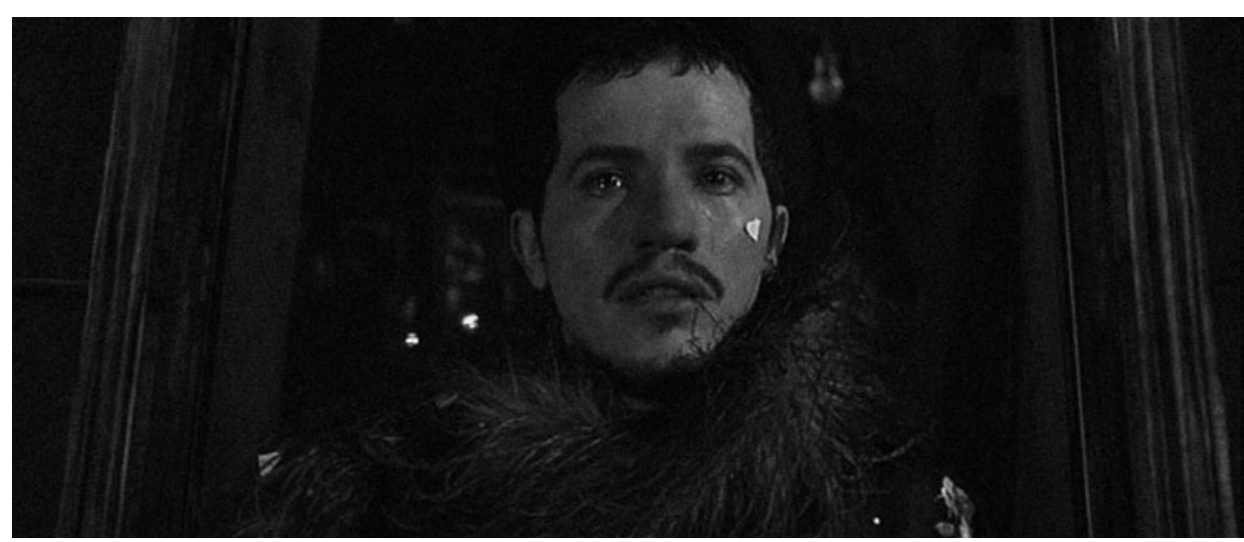

Moulin Rouge! Toulouse-Lautrec as Harlequin, the choir' character influencing the course of events.

all other stories is the love story. Toulouse also stands behind multiplied narrative strategies. Through him as a character it is possible to identify that the process of writing the story that seems to be the all governing principle in the film actually leads back to the theatrical forms of narration.

Although Moulin Rouge! travels to the recipient through the film medium, the director composes the whole story as an event from behind the red curtain. The red curtain welcomes the audience already at the very beginning of the film when the film production studio credits (20th Century Fox) appear on the screen stylised as an event when the red curtain opens up accompanied by the jingle music played by live orchestra with a conductor, and revealing the name of the company. The spectators know they enter the fictitious world with its own rules tied to the reality of physical world loosely. It is a play, an arranged event, a performance that needs stylisation, stage design, masks and multiplication of characters identities on various stages, diverse spaces where situations in the film can be staged. Such reading of the musical Moulin Rouge! can be understood as the self-referential examination of staging principles and the development of entertainment forms. The spectator is lead together with the camera movement in Moulin Rouge - in the ballroom, cabaret, theatre - the contemporary underworld, watches the show that is a blend of Hollywood, and Bollywood production and all that in one film. The development of mass culture forms can be observed, the development of popular culture can be traced - this is the framework in which the film as a metacinematic/self-referential examination of entertainment forms and staging principles overlaps with the story of a place that the film is the interpretation of.

The story whose main theme is time can be identified in the story of a specific period. The story on the time of fruitful decadence providing the audience with the reconstruction of Cultural Revolution in one debaucherous Parisian district. The story of the part of European cultural history narrated as the individual history of one love, a life experience of a writer. The history of place and period is transformed into "his story", as if the narration could make sense only then if the events of the past years are re-evaluated in the perspective of a specific human experience. The priority of authentic experience is the methodological priority of the whole concept in Moulin 
Rouge! and therefore in spite of the ties to historical background the film is not a historically realistic, factual narrative, the ties of the film lie on the level of aesthetic, and emotional experience. The film mediates the experience of the specific time and one of the authentication referents of the time is also a bohemian dwarf Toulouse. A paraphrase of painter Toulouse Lautrec does not require the referential correspondence with historical facts, because Toulouse functions as an icon of the time, as a symptom, the essence of bohemian life, he is more a myth, than a reality. Perhaps no other person can be believed more in his faith in bohemian revolution - truth, beauty, freedom, and love - than Toulouse, the decadent, and idealist.

The ideals of bohemian revolution are not only repeatedly verbalised narration topic, they also determine the aesthetics of the whole film. Freedom, beauty, and truth are in Moulin Rouge! present as camp, in which the life style fuses with the carnival event. In this permanently liminal, ambivalent, fluid, relative, and relativising expression camp is as truthful as a harlequin accompanying the audience throughout the whole story.

The musical language in the film is marked by eclecticism, present everywhere, as blending, hybridisation on the level of style and aesthetics of diverse cultures. The hybridity corresponds with the logic of camp, as well as with the principle of intertextual ties. The creators admit that they are fully aware of the fact "everything has been here", however, they remind the spectator not to forget about it. They recycle old stories, borrow iconically known images into visual compositions of particular scenes and shots, however, above all the whole musical production used in the musical is presented as one big paraphrase, or to put it more precisely the collage of citations and allusions of popular hits. Moulin Rouge! is a musical pastiche that pays respect to used pretexts, however, it is not afraid to shift their expression and semantic assumption if it serves the function, as well as it does not fear to change the musical rhetorics for the aesthetics of video clip ellipsis that moves the film most remarkably away from the theatre rhetorics.

\section{Theatre - Source Code of Film Language}

Australia (2008) $)^{27}$ is the project that has minimal qualities of a theatre event. It almost gives up the theatre language in favour of film narration and since the vast, extraordinary country is in the title role of the film it literally revels in possibilities of camera and film image. It seems that respecting the tradition (which in fact plays central role in this project) the beginning of the story is connected with theatre acting forms such as the declamation effect and expressive gestures. The effect of dramatically exposed face miming on stage is strengthened by film techniques, such as the work with camera, shot, and editing. The more intensively the protagonist Lady Sarah Ashley blends in the country and understands the mentality of Aboriginals, the more naturally she acts.

Schiaparelli and Prada: Impossible Conversations $(2012)^{28}$ is the series of approximately two-minute discussions between two icons of the fashion world that could not have happened in real. The director does not use the film montage but a theatre

\footnotetext{
${ }^{27}$ Australia, directed by B. Luhrmann. UK/Australia/USA, 2008. $165 \mathrm{~min}$.

${ }^{28}$ Schiaparelli and Prada: Impossible Conversations, directed by B. Luhrmann. USA, 2012, 8x3 min.
} 


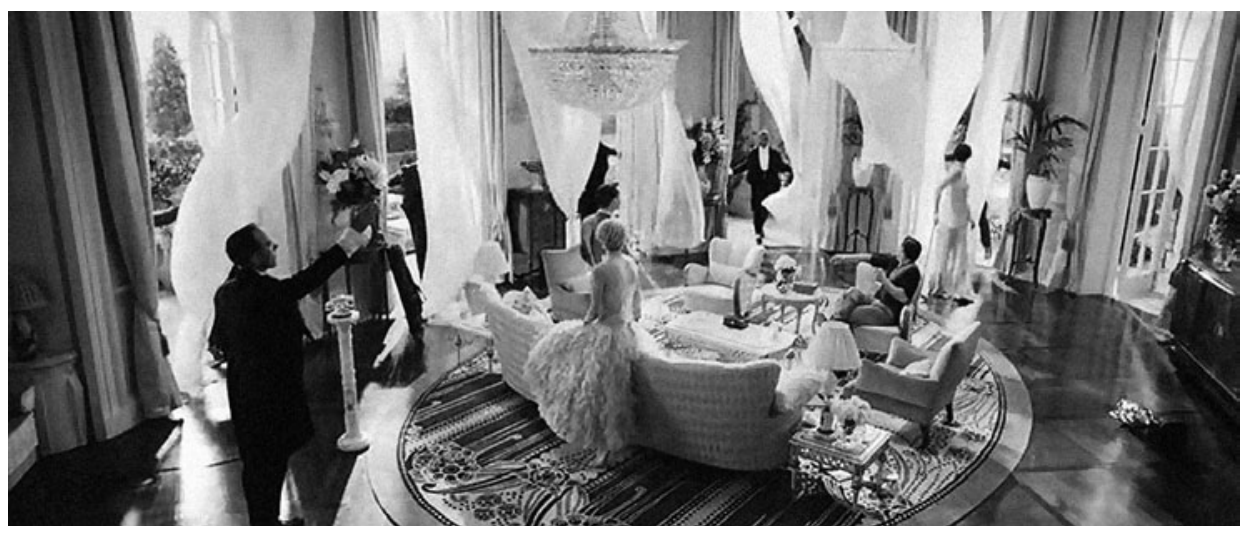

The Great Gatsby. Each film shot is a perfectly orchestrated event on the stage.

simulacrum based on the simple principle of staging a dialogue at the table. On one end of the table there is Elsa Schiaparelli (acted by Judy Davis) on the other end there is Miuccia Prada (herself) between them a carafe and glasses, the wall full of paintings in decorative frames stands out behind them. The overall image is theatrically stylised as a cut-out from a relatively static scene on a stage. Taking into consideration the director's interest in aesthetic gaudiness the scene is relatively decently arranged, although it is impressive, thanks to the dominant decorative glass chandelier in the centre of the shot. In the foreground the protagonists of the dialogues stand out on the dark background. They discuss how they perceive fashion in relation to art, experiment, beauty, body, self-expression, and globalisation. Film interventions into the theatrical material, i.e. the alternating shots (mostly full shots, and medium closeups), the subtitles serve both purposeful but also aesthetic functions, turn seemingly ordinary theatre performance recording to a brilliant concept where chronotopic dimensions of "here and now" and "then and there" intersect. ${ }^{29}$

The Great Gatsby (2013) ${ }^{30}$ is most of all the adaptation of a literary pretext and it is exactly this intertextual link that Luhrmann tries to accentuate. On one hand he understands the book by Francis Scott Fitzgerald as a material well suited for the film - "it's a compressed book with a lot of density", on the other hand he realises the possible problems when adapting it for the screen - "it's almost all entirely internal, it's an internal narrative of Nick Carraway. ${ }^{\prime 31}$ He solves the limits of the internal narration in a few ways. To make the story realistic as a narrative, and to reveal the motivation of the narrator - he adds the role of a psychiatrist who not only encourages Nick hesitating to write off the suffering but he is also the reader and listener to the story. As a result the story can be presented in the film in various forms enabling the

\footnotetext{
${ }^{29}$ The projects started as a part of the exhibition of the same title held in the Costume Institute of Metropolitan Museum of Art in New York in 2012. The individual short films correspond to eight thematic sections of the exhibition: The Surreal Body, Naif Chic, Ugly Chic, The Classical Body, The Exotic Body, Waist Up/ Waist Down, Hard Chic, while the first film has the title identical with the title of the series. For more see at: https://www.metmuseum.org/exhibitions/listings/2012/impossible-conversations.

${ }^{30}$ The Great Gatsby, directed by B. Luhrmann. Australia/USA, 2013. $143 \mathrm{~min}$.

${ }^{31}$ Discussions from the bonus material on Blu-ray disc of the film The Great Gatsby.
} 


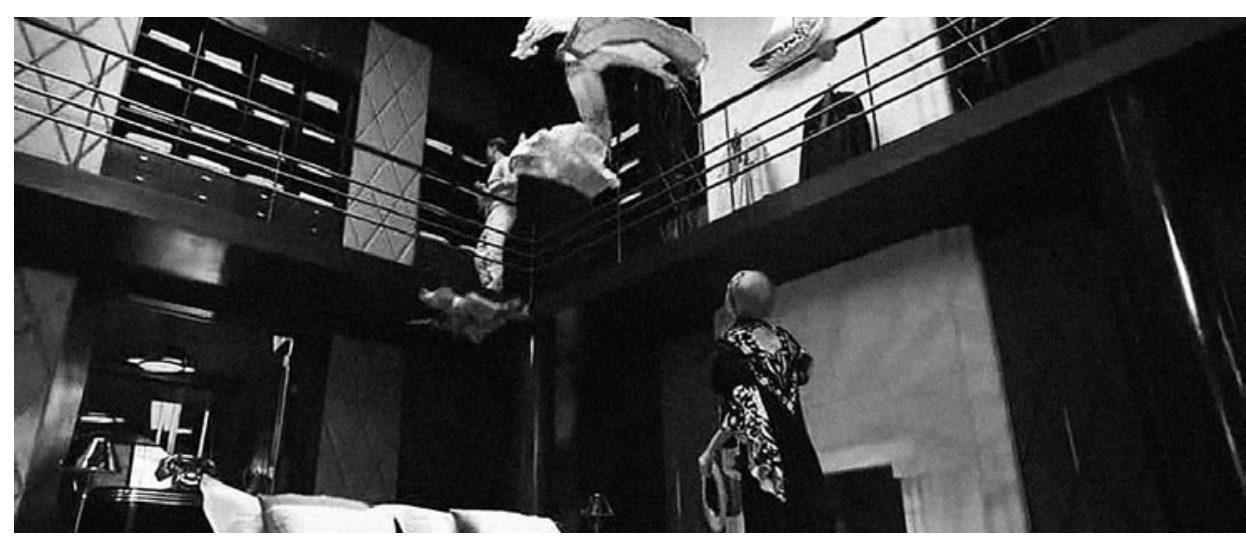

The Great Gatsby. The balcony scene of the lovers is also present in this story, however, it is a very loose allusion.

exchange of a static, theatrical - less believable and unattractive - internal monologue in the film for a complex cinematic experience.

The director, using his own words creates a "cinematic poem"32 when he dynamically changes dramatic scenes with poetic notes, these are materialised in three planes in image and sound at the same time. The film image, as it is constructed in the film The Great Gatsby, is above all the homage to film montage, a characteristic narrative principle in silent film of the twenties in the $20^{\text {th }}$ century, this time however, in the $3 \mathrm{D}$ version. In this film project theatricality is subdued to cinematic language, although the ostentatious aesthetics characteristic for the creative team Baz Luhrmann - Catherine Martin remains a recognisable feature of artistic poetics. It is revealed in the meticulously arranged mise-en-scène, the aestheticised production design, in the exemplary connection between the authenticity of the presented period and the modern feeling rendered by costumes, and music. Music is here not only a 'stage prop', it is an equally significant counterpoint to the visual image. In addition to the exuberant carnivalesque show of music and dance - there are two other elements that link the film with theatre. The omnipresent spectator, the one who looks at "here and now", is the first example. The illusive quality belonging rather to theatre than to life is the second example. Both elements are presented in the film in style and theme. Gatsby stages his life - literally - in such a way that he can put it on a display, it is a swanky life, and thus can attract Daisy. The whole performance of his life is for her, he arranges the stage into smallest details - for her, she is the intended spectator. The problem, however, is that she is a model spectator formed by Gatsby's desires, and dreams. Daisy is the materialisation of his imagination, a relic, to who he looks with adoration; she is the illusion, fantasy, a green light across the bay. Everything he achieves, and does is the materialisation of his grandiose imagination, thus Gatsby's stage, and Luhrmann's stage are identical - the same space where staging takes place. 
The Get Down $(2016-2017)^{33}$ is the latest project of Luhrmann's oeuvre. It is a TV show, a good example of a current tendency to create so called "quality TV". Compared to film and theatre it has an advantage (in addition to budget and auteur's freedom) - time. All the time that a creator needs to narrate a great epic story where in the centre is still the leading couple of romantic heroes. The director, however, does not narrate their story, but the story of the epoch when one of the global subcultures that principally redefined our present came to birth. The historic authenticity of The Get Down, the TV series situated in the end of the seventies of the past century, lies mostly in its subtle production design. It narrates a meta story of the birth of hip-hop as a subculture standing on three pillars (graffiti, breakdance, DJing, and rap), while it conveys the cultural upheaval in the racially, socially, and economically segregated milieu of a ghetto in a metropolis. It gave rise to the new original (sub)culture that from the Bronx, a New York borough, spread all over the world in about forty years.

Although formally it may seem that the affinity with theatrical strategies, and language has evaporated, on the thematic level the fascination with theatre forms is very clear, because what is examined in film techniques, is the play principle in the culture, as it has been described in its quintessential form by Johan Huizinga in his groundbreaking study of play as a productive principle in culture. ${ }^{34}$ Rap battles, as they are presented in the TV show by Luhrmann, are events of poetry making, a social game with clearly identified elements of competition, the archaic poetry making understood as an agon/conflict, and they exist in the cultural tradition all over the world. Rhymed word exchanges, ridiculing, an idea, allusion, improvisation, wordplay, riddle, provocation, challenge, and response - these are the elements the dynamics of the image and sound in the series is based on. The TV show is fully subject to the internal rhythm of subculture coming to birth on stages in provisional night clubs. There is a very simple motivation behind it - to be heard, to be seen, to perform, and to be remembered.

\section{Conclusion}

The theatricality, a marked feature of Luhrmann's film oeuvre that helps to recognise him as an auteur, can be identified in various degrees in all his projects. For the first three projects referred to together as the Red Curtain Trilogy, the theatricality is defining. The director verifies the relationships between various types of stage, and staging strategies, and among elementary expressive means of theatre - dance, music, and poetic language. The specific characteristics of Luhrmann's directorial style were formed in the trilogy - aesthetic ostension, camp, and citation as an elementary basis of intertextual coding; they are the assertion of the performative vision of the world. The aesthetics of film image in Baz Luhrmann's movies is the result of complex cooperation with the costume designer Catherine Martin. It is the example of symbiosis between the theatrically stylised mise-en-scène, and the visual qualities of the film image. sodes).

${ }^{33}$ The Get Down (TV series, creators: Stephen Adly Guirgis, Baz Luhrmann, USA, 2016 - 2017, 11 epi-

${ }^{34}$ HUIZINGA, J. Jeseň stredoveku. Homo ludens [The Autumn of the Medieval Ages. Homo Ludens]. Bratislava : Tatran, 1990, pp. $301-312$. 
Even in his later projects where the cinema quality dominates, the theatricality remains present in the source code of the film language. It can be observed in the meticulously arranged mise-en-scène, minutely aestheticized set and costume design, carnivalesque experience, and the functional, expressive stage design collaborating with music. In Luhrmann's projects the music always plays an equal counterpart to other film elements, emotionally and semantically. The music evokes both - the authenticity of the period, and modern feeling. The same happens with exquisite costumes. The omnipresence of spectators - watching all that is displayed in front of their eyes - affirms that the Luhrmann's film projects are embedded in, and coded by theatre. Luhrmann always creates an event that is staged, orchestrated, and therefore autoreferential. Even when there are ties to extratextual reality in his films, he is not interested in the referential identity with the reality, he is invested in creation of an illusion that will facilitate the period experience, and convey the authentic artistic experience for the audience. Therefore his film performances are first of all carnivalesque experience. They are autonomous in the process of reception, however, as intertexts they absorb fragments of various texts; they acquire the codes of diverse languages, and convey a clear worldview with no claim to the hierarchisation of resounding languages. They are an elaborated embodiment of Bakhtin's dialogical genre, and a purposeful development of Kristeva's carnivalesque discourse.

The study is an output of the grant project KEGA 033UKF-4/2019 Popcultural Studies as a Platform for Revitalisation of the Humanities.

\section{Translated by Alena Smiešková}

\section{LITERATURE}

DUNTON-DOWNEROVÁ, Leslie - RIDING, Alan. Shakespeare. Základná príručka [Essential Shakespeare Handbook]. Bratislava : Ikar. ISBN 80-551-1291-6.

ECO, Umberto. Jak interpretovat seriály [Interpreting Serials]. In ECO, Umberto. Meze interpretace [Limits of Interpretation]. Praha : Univerzita Karlova, 2004, pp. 93 - 109. ISBN 80-2460740-9.

HUIZINGA, Johan. Jeseň stredoveku. Homo ludens [The Autumn of the Middle Ages. Homo ludens]. Bratislava : Tatran, 1990. 383 p. ISBN 80-222-0211-8.

LUHRMANN, Baz - MALONE, Peter. Baz Luhrmann. Interview, 19. 12. 1996. [online]. [cit. 10 May 2020]. Available at: http://petermalone.misacor.org.au/tiki-index.php?page=Baz+Luhrmann\&bl.

LUKEŠ, Milan. Mezi karnevalem a snem. Shakespearovské souvislosti [Between Carnival and Dream. Shakespeare and the Others]. Praha : Divadelní ústav, 2004. 368 p. ISBN 80-7008-158-9.

MALÍČKOVÁ, Michaela. Vo vedlajšej úlohe: chór - mág - šašo - harlekýn [Also Starring: Choir-Magi-Fool-Harlequin]. In Kino-Ikon, 2002, Vol. 6, Issue 2, pp. 197 - 200. ISSN 13351893.

MALÍČKOVÁ, Michaela. Významotvorná povaha medzitextových väzieb v popkultúrnych textoch [Making Meaning through Intertextual Links in Popculture Texts]. In Teória umeleckého a prekladového textu: tradície a inovácie [Theory of Artistic and Translation Text: Traditions and Innovations]. Nitra : UKF, 2015, pp. 167 - 188. ISBN 978-80-558-0908-3.

ORAVEC, Peter et al. Praktická estetika 10 : O interpretácii dramatického diela [Practical Aesthetics 10: On Interpretation of Drama]. Nitra : UKF, 2015. 101 p. ISBN 978-80-558-0910-6. 
OSOLSOBĚ, Ivan. Principia parodica totiž Posbírané papíry převážně o divadle [Principia parodica i.e. Collected Papers on Theatre]. Praha : Akademie múzických umění, 2007. 358 p. ISBN 978-807331-082-0.

PLESNÍK, Lubomír et al. Tezaurus estetických výrazových kvalit [Thesaurus of Aesthetic and Expressive Qualities]. 1. vydanie [1st edition]. Nitra : Univerzita Konštantína Filozofa, 2008. 472 p. ISBN 978-80-8094-350-9.

SHAKESPEARE, William. Tragedie I. [Tragedies I]. Praha : Státní nakladatelství krásné literatury, hudby a umění, 1958.

SOURIAU, Étienne. Encyklopedie estetiky [Vocabulaire d'esthétique]. Praha : Victoria Publishing, 1994. 944 p. ISBN 80-85-605-18-X.

SONTAG, Susan. Poznámky o fenoménu camp. [Notes on "Camp"]. In Labyrint Revue, 2000, Vol. 8, Issue 7 - 8, pp. 79 - 86. ISSN 1210-6887.

TATARKIEWICZ, Władysław. Dejiny estetiky I. Staroveká estetika [History of Aesthetics. I: Ancient Aesthetics]. Bratislava : Tatran, 1985. 528 p.

THOMPSONOVÁ, Kristin - BORDWELL, David. Dějiny filmu. Přehled světové kinematografie [Film History: An Introduction]. Praha : Akademie múzických umění a Nakladatelství Lidové noviny, 2011. 848 p. ISBN 978-80-7331-207-2.

ŽILKA, Tibor. Text a Posttext [Text and Postext]. Nitra : Vysoká škola pedagogická, 1995. 161 p. ISBN 80-88738-58-X.

Michaela Malíčková

Ústav literárnej a umeleckej komunikácie

Filozofická fakulta UKF v Nitre

Štefánikova 67

94974 Nitra

Slovakia

e-mail: mmalickova@ukf.sk

Juraj Malíček

Ústav literárnej a umeleckej komunikácie

Filozofická fakulta UKF v Nitre

Štefánikova 67

94974 Nitra

Slovakia

e-mail: jmalicek@ukf.sk 